\title{
Conceptualising a biophilic services model for urban areas
}

\section{Author Details:}

\section{Dr Omniya el-Baghdadi}

Queensland University of Technology; Brisbane, Australia

2 George Street Brisbane, Queensland, Australia 4001

Omniya.elbaghdadi@gmail.com

\section{Dr Cheryl Desha}

Queensland University of Technology; Brisbane, Australia

2 George Street Brisbane, Queensland, Australia 4001

Cheryl.desha@qut.edu.au

\section{Corresponding author: Omniya el-Baghdadi}

\section{Structured Abstract:}

The recent United Nations Framework Convention on Climate Change Conference of the Parties ('COP 21') indicated that world leaders are now actively exploring solutions to address the consequences of global warming. One area of consideration is the built environment. A number of challenges have emerged due to the current design of most major cities. The notion of Biophilic Urbanism refers to the use of natural elements as purposeful design features in urban landscapes in order to address climate change issues in rapidly growing economies.

Five case studies and twenty six interviews were conducted to interrogate examples of successful biophilic cities Portland, Chicago, Toronto, Berlin and Singapore. This investigation was conducted to capture the method of economic enquiry used to inform Biophilic Urbanism. Findings indicated the explicit or implicit use of ecological knowledge in decision making.

We present an extension to the theory of ecosystem services in the form of 'biophilic services', which we propose play an influential role in informing decisions regarding whether to incorporate biophilic urbanism in city environments. We also present the underlying logic that appears to be informing biophilic urbanism. The existing Ecosystem Services model for decision making is adapted to provide a decision making flow for biophilic urbanism. Not only do 
the components of the model (i.e. 'Pressure', 'Context of Value', 'Biophilic Services' and 'Valuation') accommodate the iterative, snowballing dynamism necessary within biophilic-related decisions; the model also highlights the significant role of each component in informing the final decision.

We conclude from this study a number of opportunities for governments, as well as for other stakeholders involved in the decision making process, to use economics in a holistic way to strengthen the case for biophilic urbanism.

Keywords: Biophilic Decision model; biophilic urbanism; built environment; decision making; ecosystem services 
Highlights

- Biophilic urbanism refers to the use of natural design features in urban settings.

- It is capable of addressing climate change challenges in cities.

- There is currently an ad hoc economic assessment approach of biophilic urbanism.

- The economics of biophilic urbanism needs attention to provide a complete analysis.

- A holistic model for economic enquiry into biophilic urbanism is proposed. 


\section{Introduction}

There is an urgent need for all countries around the world to engage in addressing climate change mitigation and adaptation. Global greenhouse gas reduction targets were produced at the 2015 United Nations Framework Convention on Climate Change Conference of the Parties ('COP 21'). This includes, for the first time, requirements that all parties report regularly on their emissions and implementation efforts, and undergo international review (Centre for Climate and Energy Solutions, 2015). The built environment is a major focus area in plans to reduce greenhouse gas emissions, and is also acutely vulnerable to the impacts of climate change (Grimm et al., 2008, Smith et al., 2010). The current design of most major cities contributes to both mitigation and adaptation challenges, exacerbated by increased urbanisation and population pressures. This includes increased congestion, rising fossil-fuel based energy consumption and concrete-laden construction techniques, in addition to rising urban heat island effects, particulate pollution, health implications (Beatley, 2011, 2012).

Within this complex and multidisciplinary problem context, and moving beyond the prevalence of ad hoc and incremental sustainability improvements that have been made to date, step-change collaborative efforts are required to find rapid and transformational solutions (Reeve et al., 2015; Hargroves et al., 2016). Complex problems often require a multidisciplinary approach to comprehensively address an issue. According to the United Nations (UN) report by the Department of Economic and Social Affairs (2013), sustainable development requires ambitious and collaborative efforts to systematically reduce inequality, encourage the protection of natural assets, and strengthen economic governance. This is further highlighted in the UN Sustainable Development Goals (SDG), which presents a comprehensive agenda suggesting the need for collaborative efforts (United Nations, 2015).

Linking sustainability, design and ecology, the notion of biophilic urbanism presents a unique opportunity to create sustainable and liveable cities to promote enhanced well-being (Beatley, 2011; Desha et al., 2016). Biophilic urbanism represents the idea of integration of urban nature into cities and proffers a design principle to inform intentional and functional use of natural or "biophilic" elements, such as city and pocket parks, linear green space, and green roofs and walls in the built environment (Beatley, 2011). The term biophilic urbanism stems from E. O. Wilson's physiological principle of biophilia, which suggests that there is an innate bond between living systems and humans (Wilson, 1984). This intrinsic bond refers to the subconscious connections that human beings seek with the rest of life. Similarly, Ulrich et al. (1991) described the restorative influence of nature on human beings' well-being derived from the psycho-evolutionary theory. Following a stressor, this theory explains that exposure to nature creates a shift in feelings towards a more emotionally positive state, positive changes in activity in various 
physiological systems, and even moderately high levels of sustained attention. This theory further exemplifies that human beings are innately aesthetically attracted to natural content.

Extending the principle of biophilia and the psycho-evolutionary theory to city design, biophilic urbanism proposes the incorporation of intentional natural design features across cities, neighbourhoods and buildings to offer daily exposure to natural systems (Beatley, 2011). Biophilic urbanism understands that human beings are a part of the ecosystem and focuses how cities should be designed to protect each resident at the individual level. This suggests a holistic approach in the way cities are designed to create socially optimal outcomes. Given that the globe's top 600 cities are projected to account for about 60 per cent of global GDP in 2025, opportunity exists for biophilic urbanism as a means to address the plethora of urban-related problems noted above, while improving productivity and increasing biodiversity in our urban environments (Dobbs et al., 2011).

There are a number of emerging factors conducive to successfully embracing biophilic urbanism, observed globally in cities that have integrated nature within their built environments (Newman, P. et al, 2012; Reeve, 2014; el Baghdadi, 2016). This includes the need for economic understanding of the decision making process for integration. Existing literature on the economics of biophilic urbanism has started to create links between natural design features (i.e. biophilic elements) and its monetary impacts on various sectors of the economy (for example Terrapin Bright Green, 2012; Bilsborough, 2014). This provides a starting point; however the decision making process and systematic economic understanding of biophilic urbanism remains poorly understood (el-Baghdadi et al., 2014).

Within this context, the objective of this study is to uncover a clear method of economic enquiry that could overcome barriers to decision making related to uncertainties about capital and operational costs of biophilic elements. In doing so, this study facilitates understanding of the decision making process that appears to be employed by stakeholders. This paper also offers a better understanding of the functionality of biophilic elements, further exemplifying their significant potential in the built environment.In Section 2, the research methods are presented, which includes a systematic literature review, case study research, and semistructured interviews. These methods are used to reveal examples of the successful implementation of biophilic elements. This section also explains the data analysis process and results are presented in Section 3. Subsequently, we discuss how the ecosystem services approach can be used to derive 'biophilic services', which can enhance well-being. These biophilic services: encompass various conditions and processes; can be characterised as direct or indirect; can be conceived as implicit or explicit; and can be treated as qualitative or quantitative.To ground the conceptual model in existing theory, we adapt the framework for an integrated assessment of ecosystem and landscape services by de Groot et al. (2002). This framework links ecosystems and landscape to services, values, trade off instruments, planning tools, and financing mechanisms, presenting the conceptual flow to ecosystem services assessment to assist with decision making. We also adapt the 
Ecosystem Services Decision cascade presented by Apitz (2012), which suggests a three-part iterative conceptual framework to assist in evaluating, justifying and optimising decisions.

In all, we adapt these two frameworks to present a conceptual 'Biophilic Decision Model' that captures the pressure, decision context, and biophilic service selection and evaluation of biophilic elements to be used in a given scenario. We conclude by acknowledging the explicit and implicit role of ecology in the decision making process of biophilic urbanism. We highlight opportunities for biophilic urbanism by formally recognising 'biophilic services' in decision-making.

\section{Materials and Methods}

This study builds upon a research project that analysed biophilic urbanism in response to climate change with the Sustainable Built Environment National Research Centre (Newman et al, 2012). Specifically, the research project presented a synthesis of biophilic urbanism literature, distilling the economic and policy considerations. This study extends upon the economic component of the SBEnrc work to shed further light on the decision making process that informs the integration of urban nature into cities.

Drawing on additional review and interviews undertaken by the first author, this study involved a literature review of biophilic urbanism. Subsequently, five comprehensive case studies of cities with example application of biophilic elements were generated. The example cities - Portland, Chicago, Toronto, Berlin, and Singapore - were selected from the literature based on application of various biophilic elements (preferably successful), invocation of discussion and new ideas, and geographically dispersal to capture various contexts in terms of climate, government and community (Newman et al, 2012). We chose to explore multiple case studies, with each providing an example of a particular biophilic element, to collectively inform comprehensive attempt to green a city i.e. biophilic urbanism.

The case study research investigation protocol involved a series of questions that were used in each of the five cities to qualitatively investigate and produce consistent, comparable case study data. Government reports and academic studies were reviewed to address the series of questions. Identified gaps in the case studies were addressed through semi-structured interviews with a total of 26 participants. Interview participants were selected based on their role (government and academic) and involvement in the (relevant/respective) project. Aware of a number of various contextual factors in each of the cities, we used the case study research to add colour and weight to the hypothesised relationships articulated in the conceptual model. Analysis of the case study and interview data included:

- Data preparation: Organising the data in chronological order; coding the data; then clustering the data into meaningful categories to highlight emerging trends, themes and gaps.

- Chronological interpretations: Collected data were presented in a simple timeline narrative of each city portraying the uptake of biophilic element(s). This generated a clear narrative of each of the case 
studies as well as facilitated comparisons across cities. This helped identify the biophilic-related policy and program in each case study (see Table 1).

- Coding interpretations: The newly sorted narrative was subsequently coded using the program NVIVO. This program assists with logically categorising qualitative data, which assisted in further interpretation and comparisons between cities. Consequently, an emergent theme, push factors, were identified as part of this process. The push factor relates to the conditions that created the circumstances conducive for the uptake of biophilic element (see Table 1).

- Clustering analysis: Once the data was coded, a search for the common and conflicting economic trends within the codes were explored using the final technique, clustering analysis, was employed. Many results emerged from the clustering analysis, including 'biophilic services' and its characteristics (see Table 3), as well as the components comprising the conceptual model (see Fig. 1).

The summary of the five case studies as well as results of the first and second analysis process are presented in Table 1. The table summarises the biophilic related policy or program and biophilic element in each city (identified from the chronological interpretations); and the push factor and description (identified from the coding interpretations).

\section{- Table 1 about here -}

\subsection{Defining biophilic services}

In order to provide meaningful interpretation to the data, the literature on ecosystem services was explored. Biophilic elements are seen as 'ecosystems' ranging from individual ecosystems to city wide ecosystems (Newman et al, 2012). For the purpose of this study, green roofs, green walls and street trees are collectively considered as ecosystems within the city. Informed by the literature on ecosystem services, the identified benefits from the clustered exercise became known as 'services' from ecosystems. Ecosystem services research has become an important area of exploration over the past decade (Fisher et al., 2009). Recognising this, the idea has grown to incorporate the economic value derived from ecosystems to allow for more effective decision-making. The publication by the Millennium Ecosystem Assessment (MEA) put forward a monumental work involving over 13,000 scientists (Millennium Ecosystem Assessment, 2005). The major contribution of this work was creating clear links between the services offered by ecosystems to human welfare (Sachs and Reids, 2006; Fisher et al., 2009). Table 2 summarises some of the key definitions of ecosystem services.

\section{- $\quad$ Table 2 about here -}

The analysis of the five case studies highlighted that the push factors (summarised in Table 1), along with the economic decision making process for biophilic elements, are random, ad hoc and highly scattered, with no identified characteristics to describe and inform their use. According to the Millennium 
Assessment Framework (2005), services from ecosystems need a clear and consistent definition and wider comprehension of key characteristics of ecosystems and the services they offer.

For this reason, we have drawn from the definitions summarised in Table 2 along with the clustered analysis to offer a novel definition and characteristics of services in the built environment. The authors have coined the term 'biophilic services' to be the result of intentional biophilic interventions in the built environment that enhance well-being. The intentional interventions could be experiments or treatments in green infrastructure, which then generate biophilic services.

Table 3 summarises five characteristics to define 'biophilic services' within ecosystem services. These comprise: conditions and processes; direct or indirect benefits; implicit or explicit benefits; quantitative or qualitative benefits; and intentional interventions in the built environment.

\section{- $\quad$ Table 3 about here -}

The characteristics of biophilic services distinguish the use of urban nature throughout the city from being ad hoc to being intentional. This begins to foster understanding of the economic decision making process informing biophilic urbanism. With the characteristics identified and discussed above, the definition of biophilic services is proposed:

Biophilic services are defined as the benefits yielded from intentional interventions in the built environment, providing conditions and processes through which one or more biophilic elements yield direct or indirect, implicit or explicit, quantitative or qualitative enhanced well-being.

This definition points to the variety within services, yielding a different decision making process in each local context. This explains the difficulty in replicating biophilic elements across various contexts as characteristics vary. For example, the Toronto case study analysis found that decision-makers undertook a quantitative analysis of stormwater runoff. Their study shed light on the direct link to value and explicit understanding of the regulating services of green roofs (el-Baghdadi, 2016). This was not necessarily the same for the other case studies. Interrogating the 'Biotope Are Factor' program in Berlin highlighted that cultural services offered by urban nature did not need to be quantified nor explicitly presented in a business case (el-Baghdadi, 2016). Rather an implicit understanding of the aesthetic and recreational value in the built environment became the fundamental characteristics for the business case in Berlin.

Through uncovering the characteristics of biophilic services (i.e. Table 3 barriers to the incorporation of biophilic elements use can be addressed in any given situation. Augmenting a decision making process with tailored evaluated characteristics of the desired biophilic service could potentially address cost and information barriers for each unique context. This is discussed in the following section, where a conceptual flow model of decision-making is assembled that incorporates biophilic urbanism. 


\section{Results}

\subsection{Conceptual biophilic decision model}

The Ecosystem Service Approach is a holistic management strategy for the integrated administration of land, water and living resources that promotes conservation and sustainable use in an equitable way, based on scientific evaluation of the essential functions, processes and interactions of organisms in their environment (Convention on Biodiversity, 1998). This creates more informed and effective decisions for the economy and environment alike, yielding holistic decisions which promote and enhance well-being.

This interaction is crucial to inform decisions, and has been discussed extensively with models developed for conservation and land use planning. The foundational work laid by de Groot et al. (2002) presented a conceptual framework and typology for describing, classifying and valuing ecosystem functions, goods and services in a clear and effective manner. The concept of ecosystem services along with the prominent models, which have emerged from it were explored using the five case studies and are adapted for the biophilic urbanism context. Specifically, the exploration focused on the conceptual model linking ecosystem services to human well-being by Haines-Young and Potschin (2010), the ecosystem services framework by de Groot et al. (2002) and the decision flow diagram by Apitz (2012).

With this in mind, Fig. 1 and the following paragraphs describe a 'Biophilic Decision Model', which captures the intentional introduction of biophilic elements: an anthropocentric, ecosystem-focused framework describing the urban and human costs, and benefit opportunities of biophilic urbanism. It can be used to define links between urban related challenges and ecosystems, and ecosystems and the services that in turn mitigate and sustain those and other externalities; which are all then used to evaluate, justify or optimise decisions. This Model operates as a mechanism to an explicit or implicit challenge to introduce, maintain or enhance biophilic urbanism to promote socially optimal outcomes.

\section{- $\quad$ Figure 1 about here -}

Moving through the model, the process commences with a disturbance or pressure initiating the model flow, which could be extrinsic or intrinsic. This sets the outline for the following component, the 'Decision Context'. The context of value (i.e. what value elements are deemed significant) will determine the questions to be asked and the scope and scale of interrogation. The analysis of the state of biophysical urban status then sets the parameters for challenges or externalities to be addresses. This is followed with a set of proposed solutions i.e. the selection of a biophilic element(s). These explored explicitly or implicitly for their functionality and the services they offer through the lens of the Decision Context. This is followed with an evaluation such as cost effectiveness analysis, performance analysis, stakeholder consultation, which informs an implicit or explicit trade-off evaluation that ultimately forms the decision. The 'Valuation' together with the 'Assessment' components are influenced to various degrees by external factors such as political or societal demands. 
As the term 'flow' suggests, components of the Biophilic Decision Model overlap and inform one another. For discussion purposes in the remainder of this paper, the components are discussed separately. For each of the components (Pressure, Context, Scenarios, Assessment and Valuation), the sections discuss links between each components and theory, how the component is to be followed, and examples from practice to show how the model can be used.

Although different cities have emphasised different steps of the model; Fig. 1 illustrates the logic that forms the basis for decisions regarding the introduction of biophilic elements. Each of the cities explored in the case studies (refer to table 1 for summary of case studies) followed this processes to some extent, though in some cases, elements within the model components are suggested based on the literature (i.e. Biophysical Urban Structure and Processes) or assumed rather than explicitly addressed (i.e. Function); this is discussed in Section 3.1.2, respectively. The model emphasises the need for an explicit discussion of the decision context, assessment and valuation. Flowing from one component to the other often overlaps and/or is iterative; this will be discussed in detail in the following sections.

\subsubsection{Considering pressures in urban economies}

In the Biophilic Decision Model (Fig. 1), 'Pressures' are identified as the stressors or changes that may result from scenarios considered for the environmental plan. Intentional intervention in the built environment calls for an alternative perspective to the decision making process. The case studies demonstrated that Pressures within the urban economy prompted the initial consideration into biophilic urbanism i.e. placing it on the agenda. These pressures identified from the case studies and interviews were referred to as Push Factors in Table 1 and are categorised into meaningful Pressure categories extrinsic or intrinsic. These categories explain the context which prompted initial exploration. Hence Pressure in the Biophilic Decision Component refers to the extrinsic or intrinsic disruptions to the status quo prompting the initial enquiry into Biophilic Urbanism. Implications for this component, along with examples from the case studies, are discussed below.

\section{Extrinsic pressures}

Extrinsic pressure in the Biophilic Decision model refers to a prominent disruption in the functionality of the urban economy. This creates the first trigger for initiating the decision flow, becoming the first lens through which the decision making process is explored.

For instance, Portland and Toronto identified negative externality pressures in their respective cities. Portland was presented with the rising cost and issues of stormwater runoff, prompting an exploration into cost-effective solutions (BiophilicCities, n.d.; Water Environment Research Foundation, 2009). Government committees were then formed to explore options. This element within the Pressure Component shapes the next Component, the decision context of the government committee. Similarly, 
Toronto identified the rising costs of Urban Heat Island effect and stormwater runoff creating an obvious need for a solution (Banting et al., 2005)

\section{Intrinsic pressures}

Intrinsic pressure refers to enhancing existing conditions within the urban economy. This creates opportunities to improve conditions or avoid future risks if no action was taken. This Pressure category is often presented through community or political demand, instigated through a Champion or simply through inherent understanding of the potential in enhancing current conditions.

For instance, neighbourhood revitalisation in Chicago presented itself an opportunity to enhance existing conditions; which invigorated the precinct, providing tangible economic, social and environmental benefits (Groos and Dages, 2008; Chicago Loop Alliance, 2011). Similarly, Berlin's prominent history of urban greening cultivated a culture that appreciates and demands urban vegetation (el-Baghdadi et al., 2013). For this reason, this intrinsic pressure to go beyond the status quo presented itself as a Pressure instigating exploration into creative solutions to meet society demands.

\subsubsection{Considering the decision context}

How the pressure is processed depends markedly on the context of value and biophysical urban structure within which the pressure is experienced. The 'decision context' creates a foundation from which to explore potential scenarios to mitigate the pressure identified, framing expectations for the subsequent components of the model.

The Ecosystem Services model by Aptiz (2012) describes the decision context as the statutory, regulatory and socio-economic drivers that influence choices and decisions. These decision makers described can be private entities such as companies, stakeholder groups and nongovernmental organisations. Apitz (2012) explains that the evaluation of the decision context is crucial in informing the role services will play in decisions, as well as valuation techniques or methods selected. Hence, there is a need to understand human motivations within an evolving environment and the choices they make in the face of these changes. Understanding what choices will be made in the face of changes or pressures in the urban economy can be identified through value. It is for this reason that this component is significant. Informed by the logic of Apitz (drivers that influence decisions), the elements of this component must include: 'Biophysical Urban Structure' and 'Value'. This is because defining what constitutes value is context dependent and significant in informing the flow of the decision process. Additionally, awareness and

understanding of the urban economy dictates what drivers and other challenges could influence the following components. These are discussed in more detail below. 


\section{Context of biophysical urban structure}

The pressures identified in the previous section prompts an exploration into the current conditions providing foundational context of the situation at hand. Looking at the 'biophysical' conditions in the urban environment together with the 'context of value' described above begins to determine which services will be explored in the subsequent component.

More broadly, 'Decision Context' could be enhanced to incorporate the concept of urban metabolism. The concept of metabolism has influenced the development of theories about economic development, particularly concerned with the relationship between economic growth and urbanization resource depletion and environmental damage (Daily, 1997). Like living organisms, cities require energy, water, nutrients and effective disposal of by-products and waste to maintain optimum urban health functionality. This notion of 'urban metabolism' is a model for systematically looking at the resources that flow into cities and the wastes and emissions that flow out from them (Daily, 1997). These economic, social, or environmental 'resources' help assess the state of the urban environment and to highlight opportunities for efficiencies, improvement and transformation. This in turn informs which biophilic element(s) and respective functions and services are to be explored. Currently, the cities have not employed this concept to determine the city urban 'health' and to link these 'health' deficits with the appropriate biophilic service - a very prominent area for further research. The authors note that in-depth exploration into how this concept can be fully integrated is out of the scope of this paper, but worth exploring further in future studies.

Adapting the term 'Biophysical structure and Process' from the ecosystem models (Apitz, 2012) to the built environment, metaphorically views the built environment as a living ecosystem. Within this, it calls for scaling and scoping the decision by scanning and presenting the 'what's so' of the urban economy. This is because management of the Pressure at a site-specific scale will determine which biophilic services are needed. Hence determining the biophysical parameters will influence the decision of the following component i.e. selecting the biophilic element(s).

\section{Context of value}

As it is recognised, biophilic urbanism and sustainable related decisions are generally value-driven concepts which are strongly influenced by human perceptions. The field of neoclassical economics progressed from the individualistic element of exchange and was soon coupled with understanding human behaviour. Economists such as William Stanley Jevons and Alfred Marshall recognised the need to couple psychology with economic understanding (Backhouse and Medema, 2009). This recognised utility or value as significant to understanding how choices are made and welfare judgment considered. For this reason, understanding the Context of Value is important to determine these motivations as well as welfare judgment i.e. 'wealth' and 'wellbeing'. More specifically, the Context of Value refers to identifying the 
expectations by distilling the value component (social, economic or environmental) as well as the economic approach (i.e. quantitative or qualitative). This is discussed below, by providing examples from the case studies.

Some of the cities explored demonstrated the need to assess a market value of biophilic elements. Market value refers to the need to capture the monetary value of a biophilic element to present the costeffectiveness for city implementation. This context of value sets the tone for the rest of the flow for assessing biophilic capital. This is often informed by the pressure, however also equally informed by the decision maker's view of value. This monetary context of value was particularly seen in Portland and Toronto. These cities revealed the compelling need to present cost-effectiveness in order to proceed. This required the valuation of green streets and green roofs respectively to determine cost feasibility to counteract urban related externalities such as stormwater management and urban heat island effect (Banting et al., 2005; City of Portland Bureau of Environmental Services, 2005).

On the other hand, a different Context of Value presented itself. What was initially ambiguous and particularly contributed to the ad hoc implementation nature of biophilic urbanism is now understood that some cities did not require the quantification of a biophilic element due to the context of value. What has become clear is the interesting role of perceived value in some of the cities explored. This attitude of perceived value meant that quantitative value was not necessary due to this understood or expected value of nature in the built environment.

This was reiterated in some interviews when participants were asked to comment on compelling elements of the business case to which they explained this inherent understanding of urban vegetation (Cloos, 2012; Tan, 2013). Singapore and Berlin demonstrated traits of perceived value where monetary quantification was deemed unnecessary.

\subsubsection{Considering biophilic service selection}

Once a decision context has been defined, then scenarios, policies or actions are laid out to provide proposed solution(s). Presenting Biophilic Element(s) and selecting most appropriate option(s) links Pressure and Decision Context flows to the Service Selection Component. This means particular element/elements will be selected through proposed program(s) or policy based on the services offered. This spills over to the following component - Selection. The proposal of scenarios, policies or actions and the Selection component are not always clearly isolated and often are iterative and inform one another (as shown by light arrow on the left in Fig. 2). A proposed scenario (i.e. biophilic element), for instance, is assessed against respective functions and services. These scenarios could be fine-tuned, explored further or changed to ensure services meet Pressure and Context demands.

- $\quad$ Figure 2 about here - 
Other times the transition can be relatively linear with the proposed biophilic element(s) clearly followed with selection of functions and services (as shown by the dark arrow on the right on Fig. 2). Either way, depending on the context and biophilic element being proposed, selection will be designed to evaluate and/or quantify specific services and ways they can mitigate, improve or enhance the identified pressure to enhance well-being.

\section{Identifying function}

Pressure and Context of Value frame the lens through which the following components are looked through; this informs which biophilic functions are interrogated to yield the most appropriate services. This Function element within this component refers to the ecosystem functions that in turn provide services. One of the most cited papers in the field is the list by de Groot et al. (2002) which presented a list of ecosystem functions that they linked to goods and services. This was further popularised by the Millennium Assessment (2005). Table 4 summarises the Functions. Ultimately the selection of Functions to be considered depends on the Pressure at hand along with the Context of Value and proposed options; which will inform Biophilic Service provision. Hence Functions is the link between context and Biophilic Services, as understanding the functionality of the biophilic element will shed light on the services on offer.

\section{- Table 4 about here -}

For the Biophilic context, the Function element can also be viewed as 'categories of services'. This element is informed from the literature and was not seen in the case studies. Although, an assumption is made that implicit use of this reasoning was used to inform the subsequent element, biophilic service(s) selection.

\section{Identifying biophilic service}

As discussed, 'Biophilic Services' refer to the conditions and processes through which biophilic elements provide direct or indirect benefits to people through intentional natural design elements in the built environment. These services provide benefits and address pressures within a decision relevant context. They can be monetary or non-monetary. The previous components inform the characteristics (see Table 3 ) of any given service. The whole suite of services were summarised from the literature and discussed by el Baghdadi (2016). These services and their corresponding biophilic elements are summarised in Appendix A and B. These tables serve as a reference guide for decision makers to select the appropriate biophilic element based on the services they offer. It is important to note that these tables are not exhaustive, but rather serve as an initial guide to some of the services offered.

With this understanding, the roles of these services were explored in the five case studies along with the interviews. It is clear that biophilic services are instrumental in the business case for biophilic urbanism. 
These services address the Pressure making it compelling to progress to the following components, Valuation or at times to immediate Decision.

For instance, community as well as political pressure in Berlin created a qualitative context of value for the City. Scanning the existing urban economy to determine opportunities and challenges prompted the proposal of the Biotope Area Factor (BAF) program (Senate Department for Urban Development, 2010). Berlin's BAF program formulates basic goals and measures to ensure urban development considers the ecosystem by ensuring a sufficient ratio of ecologically-effective surface areas to total land area. This program encourages protecting biotopes and species as well enhance landscape and recreational use. In this instance, this program was initiated through an implicit selection of the cultural/ information Functions. Biophilic services, such as recreation and aesthetic value, assisted in meeting community and political Pressure. As was highlighted in the introduction, the psycho-evolutionary theory offers theoretical grounds for suggesting Berlin's emphasis on recreational and aesthetic value.

\subsubsection{Considering valuation of biophilic service}

According to Apitz (2012), the selection of valuation method or technique is based on perspective and whether they are top down (starting with high-level, often qualitative estimates of Services) or bottom-up (deriving semi-qualitative or quantitative estimates of Services from the evaluation of modelling of supporting processes) and what type of assessment approach is carried out (Apitz, 2012). The previous components described above play a role in informing the method of valuation. We notice this when coupling identified Pressure with the context of value which informs the Valuation method or technique selected.

The Valuation Component should only be as complex as they need to be, based on the Pressure and context of the decision. In some cases, a more broadly scoped but more qualitative assessment may be more relevant than a highly quantitative one that focuses on specifying the fiscal returns. The case studies demonstrated that valuation took on various forms, some of which are summarised in Appendix C.

Once the benefit valuation of biophilic service is complete a decision is made. Whether explicitly addressed or not, all management decisions and policy choices result in a decision flow. The biophilic decision making flow provides a thread by which pressures are identified and addressed as effectively as possible. The principles within this model allow for informed decision with a holistic ecological or socioeconomic perspective.

\section{Conclusion}

This paper presented the process of economic enquiry by which the business case for biophilic urbanism was investigated. We presented an extension to the theory of ecosystem services in the form of 'biophilic 
services', which we propose play an influential role in informing decisions regarding whether to incorporate biophilic urbanism in city environments. We also presented the underlying logic that appears to be informing biophilic urbanism. The existing Ecosystem Services model for decision making was adapted to provide a decision making flow for biophilic urbanism. Not only do the components of the model (i.e. 'Pressure', 'Context of Value', 'Biophilic Services' and 'Valuation') accommodate the iterative, snowballing dynamism necessary within biophilic-related decisions; the model also highlights the significant role of each component in informing the final decision.

The diversity of contexts in the case studies provides variation for investigation, but it also unfortunately means that any comparisons between the cases may be explained by these contextual factors that are specific to each location. In effect, the experiences in different contexts could be explained by omitted geographical, climate or community differences. As the case studies are really just for illustrating a theoretical model, the authors do not consider this to be an issue. However, further research is needed to disentangle these potential influences, if specific conclusions are to be made about the case study locations.

Notwithstanding these limitations, we conclude from this study a number of opportunities for governments, as well as for other stakeholders involved in the decision making process, to use economics in a holistic way to strengthen the case for biophilic urbanism. These are summarised here:

1. Stimulate change by internalising externalities: Deficits of current approaches to urban development could be used to increase the visibility and appreciation of the urgency of the challenges facing cities. This includes converting implicitly recognised externalities to explicit conversations that highlight externalities across the built environment through holistic economic evaluation. Furthermore, through identifying negative externalities we can acknowledge the benefits of biophilic services to facilitate sustainable development.

2. Communicate strategically and effectively about nature: Appreciating the complexities associated with any discussion around economic policy, the model offers mechanisms for a constructive conversation that highlights the opportunities that might exist for improvements in a nation's competitiveness and the wellbeing of its occupants, while simultaneously highlighting increased revenue opportunities and reducing cost implications. Communicating such findings clearly to the public and stakeholder groups may inform and drive an agenda for change through generating community and stakeholder buy-in.

3. Create strategic government department linkages and structures: Not only do the findings provide opportunities to enhance communication with the community and relevant stakeholders, but also enhance communication across departments. With a holistic outlook in tackling pressures in the urban economy, findings suggest linking government departments' agendas to make collective and efficient decisions. This is because focusing on a single service in isolation from other services can result in 
policy failure. Additionally, biophilic urbanism may well provide the strategic means to access opportunities without increasing tax rates, instead achieving savings through improved efficiencies in the delivery of essential services and stimulating increases in productivity.

\section{References}

1. Apitz, S. E. (2013). "Ecosystem services and environmental decision making: Seeking order in complexity." Integrated Environmental Assessment and Management 9(2): 214-230.

2. Backhouse, R. E. and S. G. Medema (2009). "Retrospectives: On the Definition of Economics." Journal of Economic Perspectives 23(1): 221-233.

3. Banting, D., Doshi, H., Li, J., Missios, P., Au, A., Currie, B. A., \& Verrati, M. (2005). Report on the environmental benefits and costs of green roof technology for the city of Toronto. City of Toronto and Ontario Centres of Excellence-Earth and Environmental Technologies.

4. Beatley, T. (2012). Green urbanism: Learning from European cities. Island Press.

5. Beatley, T. (2011). Biophilic cities: integrating nature into urban design and planning. Island Press.

6. Boyd, J., \& Banzhaf, S. (2007). What are ecosystem services? The need for standardized environmental accounting units. Ecological Economics, 63(2), 616-626.

7. Bilsborough, D. (2014). The Biophilic City: urban innovations for closing the fiscal gap. Retrieved from http://architectureau.com/articles/the-biophilic-city-urban-innovations-forclosing-the-fiscal-gap/

8. BiophilicCities (n.d). Portland. Retrieved from http://biophiliccities.org/what-are-biophiliccities/portland/

9. Centre for Climate and Energy Solutions (2015). Outcomes of the UN Climate Change Conference in Paris $-21^{\text {st }}$ Session of the Conference of the Parties to the United Nations Framework Convention on Climate Change (COP21). Retrieved from http://www.c2es.org/international/negotiations/cop21-paris/summary

10. Chicago Loop Alliance (2011). Loop Economic Study and Impact Report. Retrieved from http://loopchicago.com/_files/2011_Loop_Economic_Study_FINAL.pdf

11. City of Portland Bureau of Environmental Services (2005). Sustainable Stormwater Management: Green Streets. Retrieved from http://www.werf.org/liveablecommunities/studies port or.htm

12. Costanza, R., d'Arge, R., De Groot, R., Faber, S., Grasso, M., Hannon, B., ... \& Raskin, R. G. (1997). The value of the world's ecosystem services and natural capital.

13. I. Cloos (personal communication, November 21, 2012) 
14. Convention on Biodiversity. (1998). Report of the workshop on the ecosystem approach. UNEP Conference of the Parties to the Convention on Biological Diversity. Retrieved from https://www.cbd.int/doc/meetings/cop/cop-06/official/cop-06-20-en.pdf

15. Daily, G. (1997). Introduction: What Are Ecosystem Services? in Daily, G. (ed), Nature‘s Services. Societal Dependence on Natural Ecosystems, Island Press, Washington DC.

16. De Groot, R. S., Wilson, M. A., \& Boumans, R. M. (2002). A typology for the classification, description and valuation of ecosystem functions, goods and services. Ecological economics, 41(3), 393-408.

17. Desha, C., Reeve, A.C., Newman, P.W. and Beatley, T. (2016). "Urban nature for resilient and liveable cities." Smart and Sustainable Built Environment 5(1).

18. Department of Economic and Social Affairs (2013). World Economic and Social Survey: Sustainable Development Challenges. Retrieved from https://sustainabledevelopment.un.org/content/documents/2843WESS2013.pdf

19. Dobbs, R., Smit, S., Remes, J., Manyika, J., Roxburgh, C., and Restrepo, A. (2011). Urban world: Mapping the economic power of cities. Retrieved from http://www.mckinsey.com/globalthemes/urbanization/urban-world-mapping-the-economic-power-of-cities

20. H. Doshi (personal communication, March 16, 2013)

21. P.Y. Tan (personal communication, March 15, 2013)

22. el-Baghdadi, O. (2016). Exploring the economic business case for incorporating biophilic urbanism. PhD thesis, Queensland University of Technology.

23. el-Baghdadi, O., Desha, C., \& Hargroves, C. (2013). An exploration into retrofitting cities with natural design elements - learning from the city of Berlin, Germany. In The 8th Conference on Sustainable Development of Energy, Water and Environment Systems, 22-27 September 2013, Dubrovnik, Croatia.

24. el-Baghdadi, O., Desha, C., \& Hargroves, K. (2014). Engaging decision makers in the business case for biophilic urbanism. In Kabisch, Nadja, Larondelle, Neele, Reeve, Angela, \& Artmann, Martina (Eds.) Human-Environmental Interactions in Cities: Challenges and Opportunities of Urban Land Use Planning and Green Infrastructure. Cambridge Scholars Publishing, Newcastle Upon Tyne, pp. 12-26.

25. Fisher, B., Turner, R. K., \& Morling, P. (2009). Defining and classifying ecosystem services for decision making. Ecological economics, 68(3), 643-653.

26. Grimm, N. B., Faeth, S. H., Golubiewski, N. E., Redman, C. L., Wu, J., Bai, X., \& Briggs, J. M. (2008). Global change and the ecology of cities. Science, 319(5864), 756-760.

27. Groos, N. and Dages, M. (2008). Millennium Park: A Model for Successful Urban Green Space Redevelopment. Retrieved from https://courses.cit.cornell.edu/crp384/2008reports/12Millennium_Park.pdf. 
28. Haines-Young, R. and M. Potschin (2010). "The links between biodiversity, ecosystem services and human well-being." Ecosystem Ecology: a new synthesis: 110-139.

29. Hargroves, K., Desha, C., and Weisaecker, E.V. (2016). Energy productivity and decarbonisation of the global economy: Factor five resource productivity. WIREs, 5(1), pp. 57-67.

30. J. Oh (personal communication, March 15, 2013)

31. Millennium Ecosystem Assessment (2005). "Ecosystems and human well-being." Washington, DC.

32. National Parks (2014). Mission and History. Retrieved from https://www.nparks.gov.sg/aboutus/mission-and-history

33. Reeve, A. (2014). Mainstreaming biophilic urbanism in Australian cities: a response to climate change, resource shortages and population pressures. PhD thesis, Queensland University of Technology.

34. Reeve, A. C., Desha, C., Hargreaves, D., \& Hargroves, K. (2015). Biophilic urbanism: contributions to holistic urban greening for urban renewal. Smart and Sustainable Built Environment, 4(2), 215-233.

35. Sachs, J. D. and W. V. Reid (2006). "Investments toward sustainable development." Science(Washington) 312(5776): 1002.

36. Newman, P., Hargroves, K., Desha, C., Reeve, A., el-Baghdadi, O., Bucknum, M. ... \& Salter, R. (2012). Can biophilic urbanism deliver strong economic and social benefits in cities? An economic and policy invetigations into the increased use of natural elements in urban design.

37. Senate Department for Urban Development (2010). A Greener City Centre - Biotope Area. Retrieved from http://www.stadtentwicklung.berlin.de/umwelt/landschaftsplanung/bff/index_en.shtml

38. Smith, M. H., Hargroves, K., \& Desha, C. (2010). Cents and sustainability: Securing our common future by decoupling economic growth from environmental pressures. Earthscan.

39. Terrapin Bright Green (2012). The Economics of Biophilia. Retrieved from http://www.terrapinbrightgreen.com/reports/the-economics-of-biophilia/

40. Ulrich, R. S., Simons, R. F., Losito, B. D., Fiorito, E., Miles, M. A., \& Zelson, M. (1991). Stress recovery during exposure to natural and urban environments. Journal of environmental psychology, 11(3), 201-230.

41. United Nations (2015). Transforming out world: The 2030 Agenda for Sustainable Development. Retrieved from https://sustainabledevelopment.un.org/sdgs

42. Water Environment Research Foundation (2009). Stormwater Program Origins. Retrieved from http://www.werf.org/liveablecommunities/studies_port_or.htm

43. Wilson, E. O. (1984). Biophilia. Harvard University Press. 


\section{List of Figures}

Figure 1 - Biophilic Decision Model underlying logic informing decision making for biophilic urbanism

Figure 2 - Iterative process between options and assessment

\section{List of Tables}

Table 1 Summary of five cities and their respective biophilic policy and push factor

Table 2 Summary of definitions of Ecosystem Services

Table 3 Characteristics of biophilic services, within ecosystem services

Table 4 Summary of ecosystem functions provided by biophilic elements 


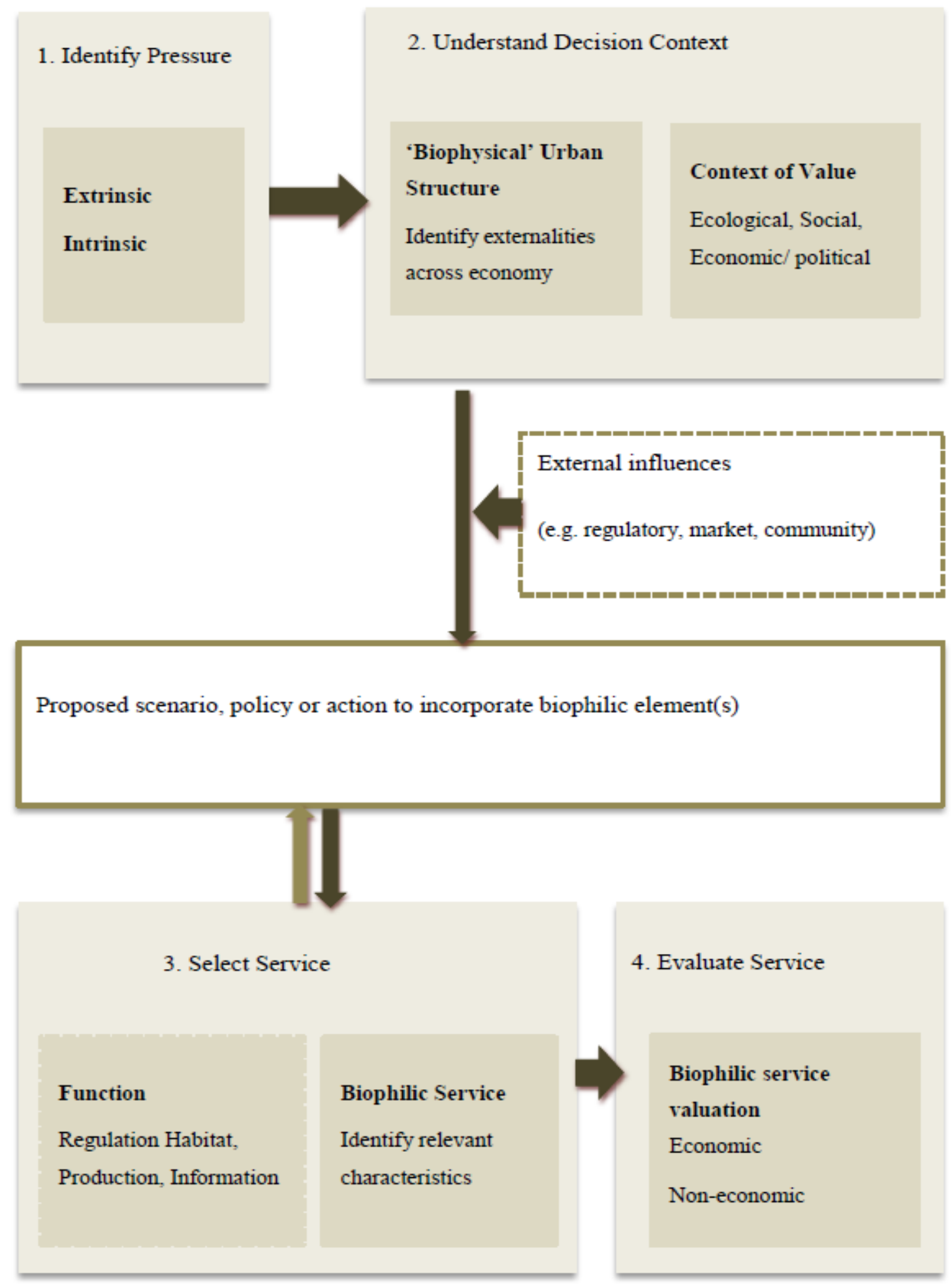

Figure 1 - Biophilic Decision Model underlying logic informing decision making for biophilic urbanism 
Proposed scenario, policy or action to

incorporate biophilic element(s)

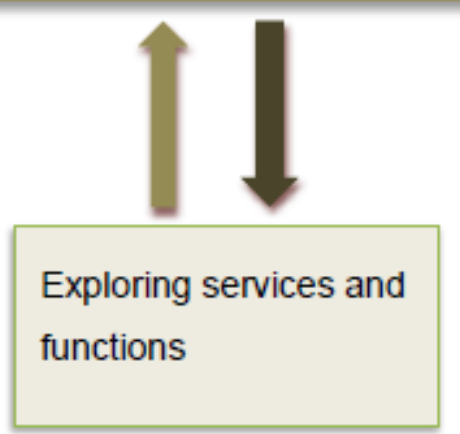

Figure 2 - Iterative process between options and assessment 
Table 1 - Summary of five cities and their respective biophilic policy and push factor

\begin{tabular}{|c|c|c|c|c|}
\hline City & Policy/Program & Biophilic element & Push Factor & Description \\
\hline Portland & Green streets policy & Green street & $\begin{array}{l}\text { Urban- related } \\
\text { challenge }\end{array}$ & $\begin{array}{l}\text { Rising issues and costs of } \\
\text { stormwater runoff }\end{array}$ \\
\hline Chicago & Millennium park & Urban Park & $\begin{array}{l}\text { Champion led } \\
\text { initiatives }\end{array}$ & $\begin{array}{l}\text { Chicago Mayor Richard M. Daley } \\
\text { actively invested in promoting } \\
\text { biophilic element(s). }\end{array}$ \\
\hline Toronto & Green roofs bylaw & Green roofs & $\begin{array}{l}\text { Urban related } \\
\text { challenge }\end{array}$ & $\begin{array}{l}\text { Rising challenges of poor air } \\
\text { quality, increased urban heat } \\
\text { island effect and stormwater } \\
\text { management issues }\end{array}$ \\
\hline Berlin & Biotope Area Factor & $\begin{array}{l}\text { Green roofs } \\
\text { Green walls } \\
\text { Community gardens }\end{array}$ & Inherent understanding & $\begin{array}{l}\text { History cultivating an inherent } \\
\text { appreciation of biophilic elements } \\
\text { in the built environment. }\end{array}$ \\
\hline \multirow[t]{3}{*}{ Singapore } & \multirow[t]{3}{*}{$\begin{array}{l}\text { Garden city } \\
\text { City in a garden }\end{array}$} & \multirow[t]{3}{*}{$\begin{array}{l}\text { Green roofs } \\
\text { Green walls } \\
\text { Street trees } \\
\text { Park connectors }\end{array}$} & Champion based & $\begin{array}{l}\text { Former Prime Minister LKY } \\
\text { envisioned and introduced policies } \\
\text { and programs, such as Garden City } \\
\text { vision }\end{array}$ \\
\hline & & & Inherent understanding & $\begin{array}{l}\text { Policies helped cultivate a culture } \\
\text { that appreciates urban nature }\end{array}$ \\
\hline & & & $\begin{array}{l}\text { Urban related } \\
\text { challenge }\end{array}$ & $\begin{array}{l}\text { Recognising urban related } \\
\text { challenges such as UHI, helped } \\
\text { introduce the 'City in a Garden' } \\
\text { program }\end{array}$ \\
\hline
\end{tabular}


Table 2 - Summary of definitions of Ecosystem Services

\begin{tabular}{|l|l|}
\hline Definition & Reference \\
\hline The benefits people obtain from ecosystems & MA, 2005 \\
\hline Ecosystem services are the ecological components directly consumed or enjoyed & Boyd and Banzhaf, 2007 \\
\hline The conditions and processes through which natural ecosystems, and the species & Daily, 1997 \\
that make them up, sustain and fulfil human life & \\
\hline The benefits human populations derive, directly or indirectly, from ecosystem & Costanza et al, 1997 \\
functions & \\
\hline Ecosystem services are the aspects of ecosystems utilized (actively or passively) & Fisher et al, 2009 \\
\hline
\end{tabular}


Table 3 - Characteristics of biophilic services, within ecosystem services

\begin{tabular}{|c|c|c|}
\hline Characteristic & Definition & Examples \\
\hline $\begin{array}{l}\text { Conditions and } \\
\text { processes }\end{array}$ & $\begin{array}{l}\text { As defined in Table } 2 \text {, the spectrum of } \\
\text { biophilic services could be considered } \\
\text { within four categories of conditions or } \\
\text { processes that yield benefits, including } \\
\text { provisioning, regulating, cultural and } \\
\text { supporting. }\end{array}$ & $\begin{array}{l}\text { Provisioning: such as shading, food, and insulation. The } \\
\text { provisioning service of insulation and shading was } \\
\text { identified in Singapore as services that yield energy } \\
\text { savings. } \\
\text { Regulating: such as air and water regulation. The regulating } \\
\text { service of water in terms of stormwater management was } \\
\text { identified in Portland, Chicago and Toronto to assist with } \\
\text { CSO. } \\
\text { Cultural: such as aesthetic value and recreation. The } \\
\text { cultural service in terms of recreation was identified in } \\
\text { Berlin. } \\
\text { Supporting: such as urban revitalisation. The supporting } \\
\text { service in terms of economic development was identified in } \\
\text { Singapore. }\end{array}$ \\
\hline Direct or indirect & $\begin{array}{l}\text { As discussed in Table 2, the services from } \\
\text { biophilic elements often yield direct } \\
\text { and/or indirect benefits to humans and/or } \\
\text { the environment. }\end{array}$ & $\begin{array}{l}\text { Direct: Connection of particulate capture to stormwater } \\
\text { quality; Indirect: Connection of particulate capture to } \\
\text { public health benefits }\end{array}$ \\
\hline Implicit or explicit & $\begin{array}{l}\text { Biophilic service may be acknowledged } \\
\text { and incorporated into the business case by } \\
\text { the user/s (i.e. explicit), or may be an } \\
\text { assumed part of the business case (i.e. } \\
\text { implicit), which may not even be formally } \\
\text { acknowledged. }\end{array}$ & $\begin{array}{l}\text { Explicit: Recognised understanding of services. Portland } \\
\text { explicitly recognised the stormwater management service } \\
\text { of green streets; Implicit: Implied understanding of } \\
\text { services. Berlin implicitly understood the social value of } \\
\text { urban greening. }\end{array}$ \\
\hline $\begin{array}{l}\text { Quantitative or } \\
\text { qualitative }\end{array}$ & $\begin{array}{l}\text { Services offered by biophilic elements } \\
\text { may be attributed to monetary } \\
\text { contributions (i.e. quantitative) or yield } \\
\text { social and environmental benefits that may } \\
\text { be difficult to be measure (i.e. qualitative). }\end{array}$ & $\begin{array}{l}\text { Quantitative: Monetary valuation of services. Toronto } \\
\text { quantified the stormwater runoff cost savings from green } \\
\text { roofs; Qualitative: Nonmonetary valuation of services. } \\
\text { Singapore identified the reduction in UHI from green roofs } \\
\text { and green walls }\end{array}$ \\
\hline
\end{tabular}


Table 4 - Summary of ecosystem functions provided by biophilic elements

\begin{tabular}{|l|l|l|}
\hline de Groot $\boldsymbol{e t}$ al & Millennium Assessment & Description \\
\hline Regulation & Regulating & Regulation of ecosystem processes \\
\hline Habitat & Supporting & Supporting for the production of all other \\
\hline Production & Provisioning & Produce products from ecosystems \\
\hline Information & Cultural & Spiritual, cognitive development, recreation \\
& & aesthetic \\
\hline
\end{tabular}


Appendix A - Direct Biophilic Services

\begin{tabular}{|c|c|c|c|c|c|c|c|c|c|c|c|}
\hline $\begin{array}{l}\text { Biophilic } \\
\text { element }\end{array}$ & $\begin{array}{l}\text { Reduce } \\
\text { absenteeism }\end{array}$ & $\begin{array}{l}\text { Increase } \\
\text { productivity }\end{array}$ & $\begin{array}{l}\text { Alleviate } \\
\text { UHI } \\
\text { effect }\end{array}$ & $\begin{array}{l}\text { Water cycle } \\
\text { management }\end{array}$ & $\begin{array}{l}\text { Reduce } \\
\text { building } \\
\text { energy } \\
\text { demand }\end{array}$ & $\begin{array}{l}\text { Increase } \\
\text { food security }\end{array}$ & $\begin{array}{l}\text { Roof } \\
\text { longevity }\end{array}$ & $\begin{array}{l}\text { Infrastructure } \\
\text { longevity }\end{array}$ & $\begin{array}{l}\text { Increase } \\
\text { property } \\
\text { value }\end{array}$ & Tourism & $\begin{array}{l}\text { Catalyse } \\
\text { economic } \\
\text { development }\end{array}$ \\
\hline Indoor plants & $\mathbf{Y}$ & $\mathbf{Y}$ & $\mathbf{Y}$ & $\mathbf{Y}$ & & & & & & & $\mathbf{Y}$ \\
\hline Green roof & $\mathbf{Y}$ & & $\mathbf{Y}$ & $\mathbf{Y}$ & $\mathbf{Y}$ & & $\mathbf{Y}$ & & $\mathbf{Y}$ & & $\mathbf{Y}$ \\
\hline Green wall & $\mathbf{Y}$ & & $\mathbf{Y}$ & $\mathbf{Y}$ & $\mathbf{Y}$ & & & & $\mathbf{Y}$ & & $\mathbf{Y}$ \\
\hline $\begin{array}{l}\text { Landscaping } \\
\text { around } \\
\text { building }\end{array}$ & $\mathbf{Y}$ & & $\mathbf{Y}$ & $\mathbf{Y}$ & & & & & $\mathbf{Y}$ & & $\mathbf{Y}$ \\
\hline $\begin{array}{l}\text { Street } \\
\text { integrated } \\
\text { trees and } \\
\text { vegetation }\end{array}$ & & & $\mathbf{Y}$ & $\mathbf{Y}$ & & & & $\mathbf{Y}$ & & & $\mathbf{Y}$ \\
\hline Shade trees & & & $\mathbf{Y}$ & $\mathbf{Y}$ & $\mathbf{Y}$ & & & & & & $\mathbf{Y}$ \\
\hline \multicolumn{12}{|l|}{$\begin{array}{l}\text { Linear green } \\
\text { space }\end{array}$} \\
\hline $\begin{array}{l}\text { Pocket parks } \\
\text { and green } \\
\text { space }\end{array}$ & & & $\mathbf{Y}$ & $\mathbf{Y}$ & & & & & $\mathbf{Y}$ & & $\mathbf{Y}$ \\
\hline City parks & & & $\mathbf{Y}$ & $\mathbf{Y}$ & & & & & $\mathbf{Y}$ & $\mathbf{Y}$ & $\mathbf{Y}$ \\
\hline $\begin{array}{l}\text { City farms and } \\
\text { urban } \\
\text { agriculture }\end{array}$ & & & $\mathbf{Y}$ & $\mathbf{Y}$ & & $\mathbf{Y}$ & & & & & $\mathbf{Y}$ \\
\hline $\begin{array}{l}\text { Urban } \\
\text { waterways }\end{array}$ & & & $\mathbf{Y}$ & $\mathbf{Y}$ & & & & & $\mathbf{Y}$ & & $\mathbf{Y}$ \\
\hline
\end{tabular}


Appendix B - Indirect Biophilic Services

\begin{tabular}{|c|c|c|c|c|c|c|c|c|c|c|c|}
\hline $\begin{array}{l}\text { Biophilic } \\
\text { element }\end{array}$ & $\begin{array}{l}\text { Reduce } \\
\text { absenteeism }\end{array}$ & $\begin{array}{l}\text { Increase } \\
\text { productivity }\end{array}$ & $\begin{array}{l}\text { Reduce } \\
\text { traffic } \\
\text { incidences }\end{array}$ & $\begin{array}{l}\text { Reduce } \\
\text { healthcare } \\
\text { cost }\end{array}$ & $\begin{array}{l}\text { Reduce stay } \\
\text { in hospitals }\end{array}$ & $\begin{array}{l}\text { Reduce } \\
\text { building } \\
\text { energy } \\
\text { demand }\end{array}$ & $\begin{array}{l}\text { Reduce } \\
\text { medication } \\
\text { intake }\end{array}$ & $\begin{array}{l}\text { Increase } \\
\text { sales }\end{array}$ & Employment & $\begin{array}{l}\text { Increase } \\
\text { sales tax }\end{array}$ & Tourism \\
\hline $\begin{array}{l}\text { Indoor } \\
\text { plants }\end{array}$ & & $\mathbf{Y}$ & & $\mathbf{Y}$ & $\mathbf{Y}$ & & $\mathbf{Y}$ & $\mathbf{Y}$ & & & \\
\hline Green roof & & $\mathbf{Y}$ & & $\mathbf{Y}$ & $\mathbf{Y}$ & & $\mathbf{Y}$ & $\mathbf{Y}$ & & & \\
\hline Green wall & & $\mathbf{Y}$ & & $\mathbf{Y}$ & $\mathbf{Y}$ & & $\mathbf{Y}$ & $\mathbf{Y}$ & & & \\
\hline $\begin{array}{l}\text { Landscapin } \\
\mathrm{g} \text { around } \\
\text { building }\end{array}$ & $\mathbf{Y}$ & $\mathbf{Y}$ & & $\mathbf{Y}$ & $\mathbf{Y}$ & & $\mathbf{Y}$ & $\mathbf{Y}$ & & & \\
\hline $\begin{array}{l}\text { Street } \\
\text { integrated } \\
\text { trees and } \\
\text { vegetation }\end{array}$ & $\mathbf{Y}$ & & $\mathbf{Y}$ & $\mathbf{Y}$ & & $\mathbf{Y}$ & & $\mathbf{Y}$ & $\mathbf{Y}$ & $\mathbf{Y}$ & \\
\hline \multicolumn{12}{|l|}{ Shade trees } \\
\hline $\begin{array}{l}\text { Linear } \\
\text { green space }\end{array}$ & & & & $\mathbf{Y}$ & & & & $\mathbf{Y}$ & & & \\
\hline $\begin{array}{l}\text { Pocket } \\
\text { parks and } \\
\text { green space }\end{array}$ & & & & $\mathbf{Y}$ & & & $\mathbf{Y}$ & & $\mathbf{Y}$ & $\mathbf{Y}$ & \\
\hline City parks & & & & $\mathbf{Y}$ & & & $\mathbf{Y}$ & & & & $\mathbf{Y}$ \\
\hline
\end{tabular}


Appendix C: Summary of Economic and non-economic valuation techniques employed by case studies

\begin{tabular}{|l|l|l|}
\hline City & Valuation technique & Sources \\
\hline Toronto & $\begin{array}{l}\text { Targeted cost-benefit } \\
\text { analysis }\end{array}$ & $\begin{array}{l}\text { Banting et al., 2005 } \\
\text { Doshi, 2012 }\end{array}$ \\
\hline Portland & Cost effectiveness analysis & $\begin{array}{l}\text { City of Portland Bureau of } \\
\text { Environmental Services, 2005 }\end{array}$ \\
\hline Singapore & Performance analysis & $\begin{array}{l}\text { National Parks, 2014 } \\
\text { Tan, 2014 } \\
\text { Oh, 2014 }\end{array}$ \\
\hline Berlin & Stakeholder consultation & $\begin{array}{l}\text { Senate Department for Urban } \\
\text { Development, 2010 } \\
\text { Cloos, 2012 }\end{array}$ \\
\hline Chicago & Stakeholder consultation & $\begin{array}{l}\text { Chicago Loop Alliance, 2011 } \\
\text { Newman et al, 2012 }\end{array}$ \\
\hline
\end{tabular}

